\title{
The Partisan Impact on Local Government Dissemination of COVID-19 Information: Assessing US County Government Websites
}

\author{
Michael A. Hansen ${ }^{1 \star}$ (D), Isabelle Johansson ${ }^{2}$, Kalie Sadowski ${ }^{3}$, Joseph Blaszcynski ${ }^{3}$ \\ and Sarah Meyer ${ }^{3}$
}

${ }^{1}$ Politics, Philosophy, and Law Department, University of Wisconsin-Parkside, 900 Wood Road, Kenosha, WI, 53144, ${ }^{2}$ Department of Sociology, Lund University and Department of Social Science, Kristianstad University, Högskolan Kristianstad, 29188 Kristianstad, Sweden and ${ }^{3}$ University of Wisconsin-Parkside 900 Wood Road, Kenosha, WI, 53144

*Corresponding author. E-mail: hansenm@uwp.edu

\begin{abstract}
This study explores the relationship between local government dissemination of COVID-19 information and partisanship. The unit of analysis is all official county government websites in the United States. In particular, we investigate if there is a correlation between the overall partisanship of a county and whether a county government's website (1) mentions COVID-19 and (2) provides safety instructions concerning COVID-19. We hypothesize that mass partisanship will impact the probability that a county government's website provides information related to the coronavirus. We find that a larger share of Democratic voters in a county is associated with an increase in the probability that a county government's website mentions COVID-19 and provides safety instructions for its residents. The results hold even after controlling for population density, internet subscriptions and COVID-19 cases and deaths. The finding indicates that citizens' access to information, even on matters of public health, are partially a consequence of partisanship.
\end{abstract}

\section{Resumé}

Cette étude explore la relation entre la diffusion d'informations sur la COVID-19 par les gouvernements locaux et la partisanerie. L'unité d'analyse est l'ensemble des sites Web officiels des gouvernements de comté aux États-Unis. En particulier, nous cherchons à savoir s'il existe une corrélation entre la partisanerie générale d'un comté et le fait que le site Web d'un gouvernement de comté 1) mentionne la COVID-19 et 2) donne des instructions de sécurité concernant la COVID-19. Nous émettons l'hypothèse que la partisanerie de masse aura un impact sur la probabilité que le site Web d'un gouvernement de comté fournisse des informations relatives au coronavirus. Nous constatons qu'une plus grande proportion d'électeurs démocrates dans un comté est associée à une augmentation

(C) The Author(s), 2020. Published by Cambridge University Press on behalf of the Canadian Political Science Association (l'Association canadienne de science politique) and/et la Société québécoise de science politique. This is an Open Access article, distributed under the terms of the Creative Commons Attribution licence (http://creative commons.org/licenses/ by/4.0/), which permits unrestricted re-use, distribution, and reproduction in any medium, provided the original work is properly cited. 
de la probabilité que le site Web d'un gouvernement de comté mentionne la COVID-19 et fournisse des instructions de sécurité pour ses habitants. Ces constatations subsistent même après contrôle de la densité de population, des abonnements à Internet et des cas et décès liés à la COVID-19. Les résultats indiquent que l'accès des citoyens à l'information, même sur les questions de santé publique, est en partie une conséquence de la partisanerie.

Keywords: partisanship; COVID-19; county websites; local governments

Mots-clés : partisanerie; COVID-19; sites Web de comté; gouvernements locaux

From the outset of the coronavirus pandemic to today, President Donald Trump's statements and actions have consistently downplayed the seriousness of the potential spread of COVID-19. For instance, in a press conference on February 26, 2020, while discussing the virus, the president stated, "And again, when you have 15 people, and the 15 within a couple of days is going to be down to close to zero, that's a pretty good job we've done" (Trump, 2020). Over the past seven months, conservative news outlets and a number of Republican politicians have adopted the president's rhetoric downplaying the virus. In fact, the president and conservative news outlets have been overt opponents of states' actions to remain under "safer at home" orders, attacking governors and local officials that support these policies. These attacks have led scholars to investigate the relationships between partisanship and public policy choices, citizen and elite attitudes and knowledge, and citizen and elite behaviour related to COVID-19 (Armstrong and Lucus, 2020; Gadarian et al., 2020; Merkley et al., 2020; Miller, 2020; Motta et al., 2020; Pickup et al., 2020; van der Linden and Savoie, 2020). One consistent finding has been that the mass public's attitudes have become increasingly polarized on the issue of COVID-19 (Gadarian et al., 2020; Miller, 2020; Motta et al., 2020; van der Linden and Savoie, 2020).

To further our understanding of the link between partisanship and issues related to COVID-19, we explore the relationship between mass partisanship and local government dissemination of COVID-19 information on official county government websites in the United States. In particular, we investigate if there is a correlation between the overall partisanship of a county and whether a county government's website (1) mentions COVID-19 and (2) provides safety instructions concerning COVID-19. We hypothesize that a county population's partisanship will impact the probability that a county government's website provides information related to COVID-19. We find that a larger 2016 Hillary Clinton vote share for a county is associated with an increase in the probability that a county government's website will mention COVID-19 and provide safety instructions for county residents, even after we control for population density, internet subscriptions and COVID-19 cases and deaths.

\section{Local Government and Mass Partisanship}

Research provides evidence that the behaviour of local-level elected representatives is related to the partisanship of the local-level population. Einstein and Kogan (2015) investigate more than 2,000 midsize cities in the United States and find 
that cities with a more Democratic population have significantly higher spending across a number of service areas. Similarly, Tausanovitch and Warshaw (2014) find that policy adoption in cities and towns with a population over 20,000 is predicted by the partisanship of the population on a liberal-conservative dimension. The findings hold across different institutional arrangements at the local level. The authors also show that presidential vote share is strongly related to the ideological profile of the city on the liberal-conservative dimension (Tausanovitch and Warshaw, 2014).

For counties, a similar relationship between the partisanship of the population and actions of elected officials is clear in current research. Percival et al. (2009) explore counties in California. The authors find that social service spending is a function of ideological orientation and that liberal counties are more likely to increase spending on welfare and social services. Choi et al. (2010) confirm these findings. Their investigation of Florida counties finds that presidential and gubernatorial vote share for Democratic candidates has a positive impact on local-level spending. Finally, Ybarra and Krebs (2010) test for a relationship between partisanship and policy that goes beyond fiscal policy. They find that Democratic vote share is predictive of a county being more likely to ban smoking in non-hospitality workplaces. The results of these studies indicate that a local-level population's partisanship may have an impact on elected officials' behaviour on a range of actions.

\section{County Government Websites}

Why explore local government websites? Local governments have the power to close, alter the hours of operation and provide additional restrictions and rules for both public and private entities to deal with COVID-19. In fact, following the Wisconsin Supreme Court's ruling on Governor Tony Evers' "Safer at Home" order, local governments are the only entity left in the state of Wisconsin with the power to enforce such COVID-19 related policies (Wisconsin Supreme Court, Wisconsin Legislature v. Palm, 2020). One could imagine that legal challenges to governors' policies in other states could end in a similar outcome. Since citizens have interactions with local government offices, public parks and buildings and/ or private businesses and entities on a near daily basis, citizens need to be aware of local government policies in order to follow the law. County government websites should publish information that allows citizens to respect the laws and regulations in place. During a pandemic, one would expect information about any county policy that has been adopted as a result of the virus. Currently, information on COVID-19 cases and deaths is reported at the county level in the United States. Since county governments have an obvious incentive to reduce the spread of the disease, one would expect that county governments would make a similarly active attempt to educate their citizens on how to stay safe.

What predicts the level of information available on local government websites generally? There are only a handful of studies that investigate the level of information available on county or local government websites, and they are limited to a subset of counties in the United States (Harder and Jordan, 2013; Bernick et al., 2014; Lowatcharin and Menifield, 2015; Baker and Chin, 2016; Bearfield and Bowman, 2017). These studies mainly focus on financial transparency, county 
board meeting minutes and other general information that is measured at the county level, such as tax information, crime records, and so on. These studies find no link between county government resources, digital infrastructure or countylevel citizen demographics (including age, race, education level, household income and poverty) and greater levels of information (Harder and Jordan, 2013; Baker and Chin, 2016). However, one consistent finding is that population or population density is associated with greater levels of information on government websites (Lowatcharin and Menifield, 2015; Baker and Chin, 2016; Bearfield and Bowman, 2017). In addition, Bernick et al. (2014) find that the mass partisanship of a county, measured as Obama's 2012 vote share, is associated with greater fiscal transparency on county websites.

\section{Partisanship and COVID-19}

There are a number of studies that demonstrate the impact that elite cues have on attitudes in the United States (Zaller, 1992; Mondak, 1993; Berinsky, 2009). These studies indicate that political elites have considerable power to frame an issue, influence public opinion in a particular direction and induce behaviour among citizens (Zaller, 1992; Mondak, 1993; Berinsky, 2009; Hansen and Dolan, 2020). As stated previously, the messaging delivered by President Trump and other prominent Republicans has consistently downplayed the seriousness of COVID-19. In fact, Green et al. (2020) find party polarization in the cues sent out by members of the US House of Representatives and Senate on the issue of COVID-19 on Twitter. In particular, the authors find that Democrats are more likely to mention threats to public health, individualized safety and American workers. Republicans are more likely to mention China, businesses, blame and opening the economy. The authors are able to correctly predict partisanship 76 per cent of the time based on the content of a tweet on COVID-19, which indicates that the response to COVID-19 aligns with the continued trend toward partisanship regarding societal issues (Green et al., 2020). Notably, the partisan impact on attitudes toward COVID-19 appears to be specific to the United States when compared to Canada. Recent studies by Armstrong and Lucas (2020), Merkley et al. (2020) and Pickup et al. (2020) demonstrate that there is either no or little to no partisan divide on the issue of COVID-19 in Canada in comparison to the United States.

There have been several studies that demonstrate that the polarization of elites on the issue of COVID-19 extends to the media and the public. Motta et al. (2020) demonstrate that right-wing media, such as Fox News and Breitbart, regularly discussed misinformation about COVID-19 in the early days of the pandemic. The authors' study finds that people who consumed right-wing media sources in the early days of the pandemic were more likely to endorse COVID-19 misinformation and to think that the health risks were being exaggerated.

These findings extend to additional studies that confirm a partisan divide in society in regard to COVID-19. A study from the Pew Research Center finds that 63 per cent of Republicans believe that the outbreak has been exaggerated, compared to just 18 per cent of Democrats who do (Mitchell et al., 2020). Further, the study finds that 68 per cent of people who indicate that they receive 
their information on COVID-19 from Trump believe that the outbreak has been made into a bigger deal than what is actually the case, compared to 33 per cent of people who receive their news elsewhere (Mitchell et al., 2020). Similarly, Miller (2020) finds that Republicans are more likely to believe in COVID-19 conspiracy theories due to their stronger political motivation to endorse such theories.

The partisan gap between Democrats and Republicans extends from attitudes to a range of behaviours. Gadarian et al. (2020) find that partisanship is the single most consistent factor that differentiates Americans' policy preferences and behaviours related to COVID-19. The study reveals that Democrats are more likely to indicate increases in activities such as washing hands, avoiding contact with others, avoiding gatherings, information seeking and self-quarantining (Gadarian et al., 2020). Finally, van der Linden and Savoie (2020) find that partisanship is a more substantive predictor of mask usage among individuals than is collective interest or self-interest. Their study finds that Democrats are more likely to report wearing a mask to prevent the spread of the virus. Given these results in previous studies, we expect that counties that are more Democratic will be more likely to provide information on COVID-19 on their websites.

\section{Dependent Variables and Method}

We explore two dependent variables. First, we code every county government website in the United States for whether the website mentions COVID-19. ${ }^{1}$ The variable was coded as 1 if there is any mention of COVID-19 on the website and as 0 if there is no mention of COVID-19. We explore all website pages that are connected to the main page. We generously code the mentioning of COVID-19. For example, if there is a statement indicating that a building is closed due to COVID-19, such as the circuit court being closed on the law enforcement webpage, we code that variable as 1 . In addition, we make use of the search function on these websites and search for use of the word COVID in order to verify whether it was mentioned anywhere on the website.

Second, we code each website for whether we could find information on how to stay safe during the spread of the virus. The variable is coded as 1 if there is any information on staying safe from COVID-19 and as 0 if there is no such information. Again, we explore all website pages that are connected to the main page. In addition, if any of the county website pages contain an external link to guidelines on staying safe from the virus, we code the variable as 1 . This occurrence was rare at the time period that we were coding the variable. However, there were a few instances where a health services webpage on the county website provided a link to safety precautions on the state's health department webpage. Finally, we make use of the search function to verify whether safety guidelines were provided anywhere on the website. The variables were coded between April 17, 2020, and April 24, 2020. The variables were coded during this condensed time period so that we could be sure that any variation in the availability of information was not a consequence of timing. We estimate individual multiple logistic regression models to predict the dependent variables. ${ }^{2}$

For each of the two variables, three researchers coded one-third of the overall county websites (around 1,000 cases). At the same time, a fourth researcher was 
assigned to code 600 county websites, with 200 counties randomly assigned from each of the three samples representing one-third of the overall data. The fourth researcher's sample was utilized to provide a coder reliability test. The intercoder reliability test uncovered zero disagreements between the coders. The simplicity of the county websites and the researchers' use of website search functions eliminated coding errors.

\section{Independent Variables}

There are five independent variables included in the multiple regression analysis. First, since previous studies exploring county government website information find that population density has an impact on the level of information (Choi et al., 2010; Lowatcharin and Menifield, 2015; Baker and Chin, 2016; Bearfield and Bowman, 2017), we include it in the analysis. The expectation is that a larger population density is associated with providing information. Next, we include two measures of COVID-19 prevalence in a county at the time of exploring the website: (1) COVID-19 cases and (2) COVID-19 deaths (Johns Hopkins University, 2020). ${ }^{3}$ Since the two variables are correlated higher than 0.80 , we estimate separate models with each of the two variables. In addition, the variables are log transformed to address issues of non-normality. ${ }^{4}$ The prediction is that a higher number of cases or deaths resulting from the virus will be associated with greater information about the virus on the county government's website. Our fourth independent variable is the proportion of each county's residents with broadband internet subscriptions (US Census Bureau, 2018). The expectation is that counties with a larger proportion of residents who have an internet subscription will be more likely to utilize their official websites to disseminate information to their residents.

Finally, a measure of mass partisanship is included in the analysis. In line with previous studies that explored partisanship's impact on county government website information (Bernick et al., 2014) and studies that demonstrated how a population's partisanship impacts local-level elected official behaviour (Choi et al., 2010; Ybarra and Krebs, 2010), we used Hillary Clinton's 2016 county vote share as a measure of mass partisanship. ${ }^{5}$ Clinton's county-level vote share was easily obtained from a number of sources, including states' election commission websites. To verify that Clinton's 2016 election was not an anomaly in terms of Democratic vote share, we test the correlation between Clinton's 2016 county vote share and Barack Obama's county vote share in 2012 and 2008. We find that Clinton's 2016 vote share correlated with Obama's 2012 vote share at 0.94 and with his 2008 vote share at 0.90 . The results indicate a clear partisanship pattern for the counties. Our hypothesis is that even when controlling for population density, internet subscriptions and COVID-19 cases and deaths, citizens of counties with a higher Democratic vote share will be more likely to receive information on the virus.

It is important to acknowledge that a number of studies uncover a relationship between elite partisanship at the local level and local-level government behaviour (de Benedictis-Kessner and Warshaw, 2016; Einstein and Glick, 2018; de Benedictis-Kessner and Warshaw, 2020). Therefore, for a subset of the sample, we test the correlation between Clinton's 2016 vote share and county government partisanship using a measure for the Democratic proportion of the county council 


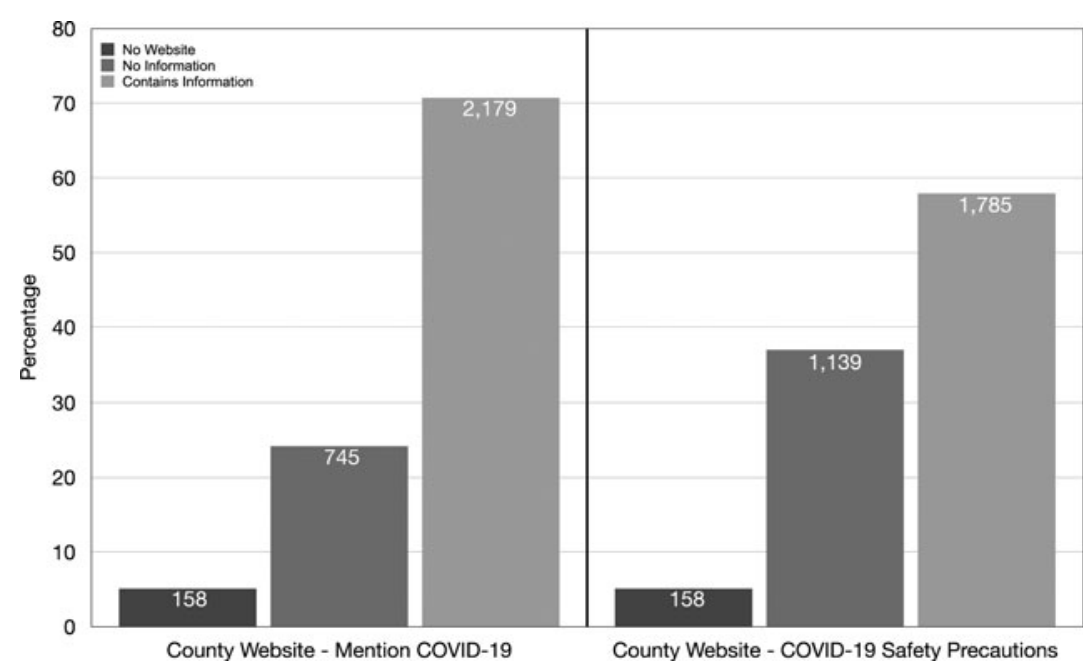

Figure 1 County Government Website Information on COVID-19

variable for years 2012-2016 from the de Benedictis-Kessner and Warshaw (2020) study. We find that the two variables correlate at 0.73 , which indicates high congruence between the population's partisanship and local elected official partisanship. ${ }^{6}$ That being said, it is important to recognize that this measure was only available for less than 10 per cent of the counties. Further, an attempt to use Clinton's 2016 vote share as a measure of elite level partisanship would be a crude proxy measure. Thus, we focus on the relationship between the population's partisanship and the availability of information on COVID-19 in the results section.

\section{Results}

In all, the analysis explores 3,082 county governments (Figure 1). ${ }^{7}$ Out of the 3,082 county governments in the United States, only 158 (5.1 per cent) had no official website. The two variables measuring the prevalence of information on COVID-19 on county government websites contained substantial variation. When exploring the counties that had official county government websites, 25.5 per cent (745) of these websites did not mention COVID-19. Rather surprisingly, more than one-third (39 per cent, or 1,139) of county government websites did not provide any information on, or link to, safety precautions in regard to the virus.

In Figure 2, we plot whether counties had mentioned COVID-19 on their website or provided safety information for the US mainland. As the top of Figure 2 displays, the counties that do not provide any mention of COVID-19 on their website are concentrated quite heavily in the central to central/southern United States. However, there are counties throughout the country that do not mention COVID-19 on their websites. In the bottom of Figure 2, we see that a lack of mention of safety precautions on county government websites is geographically dispersed. In almost every state, there is at least one county that does not provide safety information on their website. 


\section{County Website - Mention COVID-19 \\ (Apr. 17, 2020 - Apr. 24, 2020)}

ㅁ Website w/out Mention of COVID-19 ㅁ Website w/ Mention COVID-19

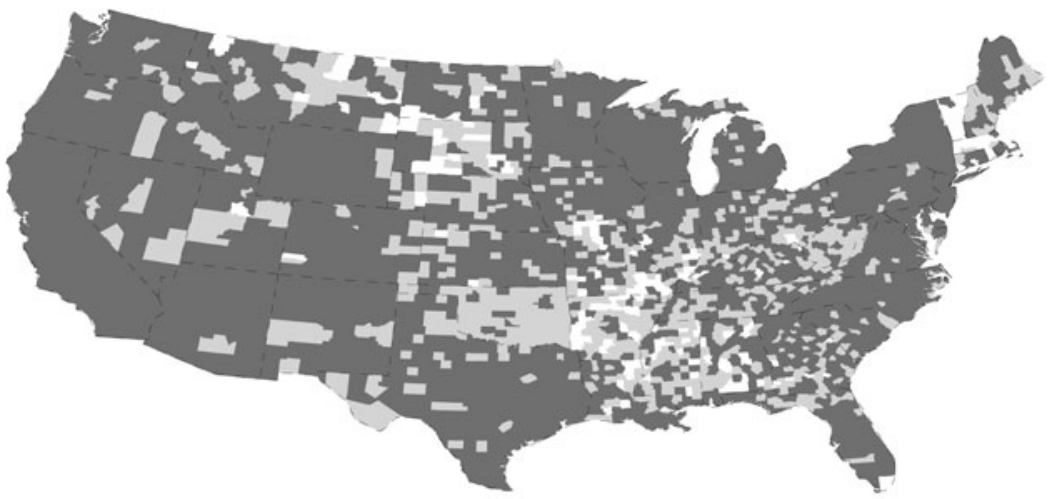

County Website - COVID-19 Safety Precautions (Apr. 17, 2020 - Apr. 24, 2020)

ㅁ Website w/out COVID-19 Safety Precautions ㅁ Website w/ COVID-19 Safety Precautions

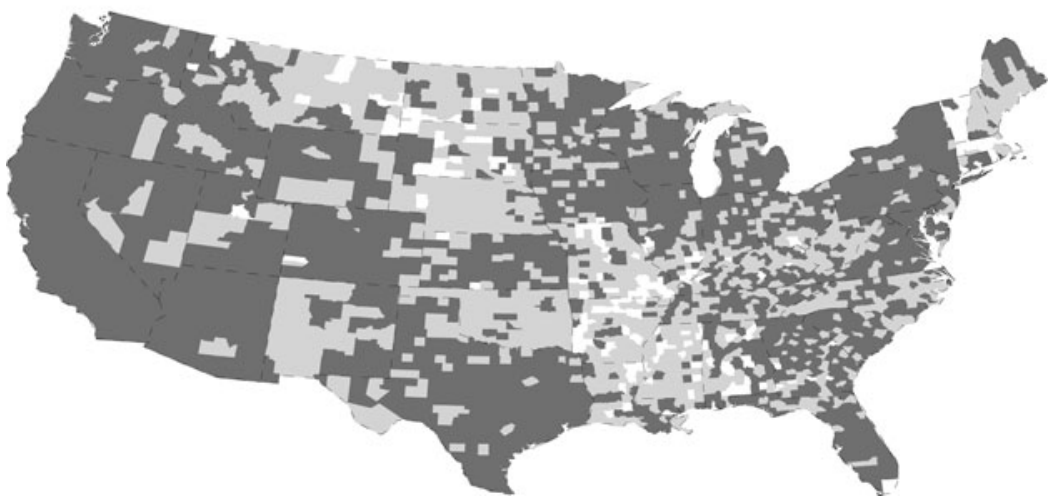

Figure 2 County Government Website Information on COVID-19: Map of Counties Note: The colour white indicates that the county did not have an official government website. Alaska only had one government website without information, and all Hawaiian government websites contained information.

In Table 1, output is displayed from four models predicting whether county government websites mention COVID-19 or provide safety precautions related to COVID-19. The results indicate that population density has no relationship with county government websites mentioning COVID-19. Surprisingly, there is a negative relationship between population density and whether a county provides safety precautions on its website. In line with expectations, as the proportion of the households in the county that have internet subscriptions increases, the 
Table 1 Models Predicting County Websites Mentioning COVID-19 and Providing Safety Information

\begin{tabular}{|c|c|c|c|c|}
\hline \multirow[b]{2}{*}{ (Intercept) } & \multicolumn{2}{|c|}{ Mention COVID-19 } & \multicolumn{2}{|c|}{ Provide safety precautions } \\
\hline & $\begin{array}{r}-5.23^{\star} \\
(0.43)\end{array}$ & $\begin{array}{r}-5.30^{*} \\
(0.44)\end{array}$ & $\begin{array}{r}-4.49^{\star} \\
(0.37)\end{array}$ & $\begin{array}{r}-4.70^{\star} \\
(0.36)\end{array}$ \\
\hline Population density & $\begin{array}{c}0.00 \\
(0.00)\end{array}$ & $\begin{array}{c}0.00 \\
(0.00)\end{array}$ & $\begin{array}{r}-0.00^{*} \\
(0.00)\end{array}$ & $\begin{array}{r}-0.00^{*} \\
(0.00)\end{array}$ \\
\hline Prop(households with internet) & $\begin{array}{c}7.20^{*} \\
(0.57)\end{array}$ & $\begin{array}{c}7.40^{\star} \\
(0.57)\end{array}$ & $\begin{array}{c}5.58^{*} \\
(0.50)\end{array}$ & $\begin{array}{c}5.98^{*} \\
(0.48)\end{array}$ \\
\hline $\log$ (COVID-19 cases) & $\begin{array}{c}0.08^{\star} \\
(0.03)\end{array}$ & & $\begin{array}{c}0.12^{*} \\
(0.03)\end{array}$ & \\
\hline $\log$ (COVID-19 deaths) & & $\begin{array}{c}0.07 \\
(0.05)\end{array}$ & & $\begin{array}{c}0.16^{*} \\
(0.04)\end{array}$ \\
\hline Clinton vote share & $\begin{array}{c}0.03^{\star} \\
(0.00)\end{array}$ & $\begin{array}{c}0.03^{\star} \\
(0.00)\end{array}$ & $\begin{array}{c}0.02^{\star} \\
(0.00)\end{array}$ & $\begin{array}{c}0.02^{*} \\
(0.00)\end{array}$ \\
\hline$N$ & 2,924 & 2,924 & 2,924 & 2,924 \\
\hline AIC & 2986.05 & 2989.95 & 3629.64 & 3634.10 \\
\hline $\mathrm{BIC}$ & 3105.74 & 3109.63 & 3749.32 & 3753.79 \\
\hline Log likelihood & -1473.03 & -1474.97 & -1794.82 & -1797.05 \\
\hline
\end{tabular}

Note: * indicates statistical significance at $p<.05$; standard errors in parentheses.

likelihood that a county's website mentions COVID-19 and provides safety precautions increases.

As expected, there is a positive relationship between the amount of COVID-19 cases in a county and whether a county government website mentions COVID-19 and provides safety information. For COVID-19 deaths, the results indicate that they are not related to mentioning the virus. However, there is a positive relationship between the number of COVID-19 deaths and a county government providing safety information on their website.

The results from Table 1 provide evidence for our hypothesis. The results indicate that there are positive statistically significant relationships between 2016 Clinton vote share and both mentioning COVID-19 on the county government website and providing safety information related to the virus. The result holds even when controlling for COVID-19 deaths and cases. The substantive impact of the vote share variable is quite large. In Figure 3, we plot the predicted probabilities of the Clinton vote share variable for the four models presented in Table $1 .{ }^{9}$ First, when controlling for population density, proportion of internet subscriptions, and COVID-19 cases, Figure 3 indicates that when comparing a county where Clinton received her lowest vote share to a county where Clinton received the highest vote share, there is an increase in the probability that a county website mentions COVID-19 of around 0.3. Similarly, when moving from the lowest to the largest values of vote share for Clinton, there is an increase of 0.25 in the probability that a county's website provides safety information related to COVID-19.

In the lower segment of the graph, predicted probabilities are plotted for the vote share variable when we control for population density, proportion of internet subscriptions, and COVID-19 deaths. When exploring COVID-19 deaths rather than the number of cases, partisanship is a powerful predictor of information on county government websites. The increase in the probability that a county's website mentions COVID-19 is larger than when we control for cases at 0.40 . That being said, the increase in the probability that a county website contains safety information 
Controlling for Population Density, Internet Subscriptions, and COVID-19 Cases
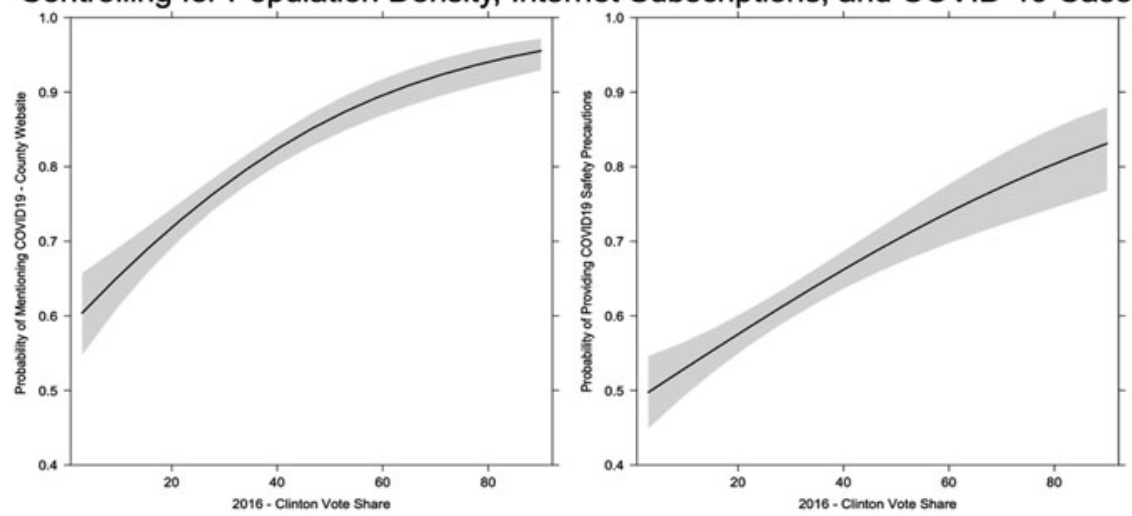

Controlling for Population Density, Internet Subscriptions, and COVID-19 Deaths
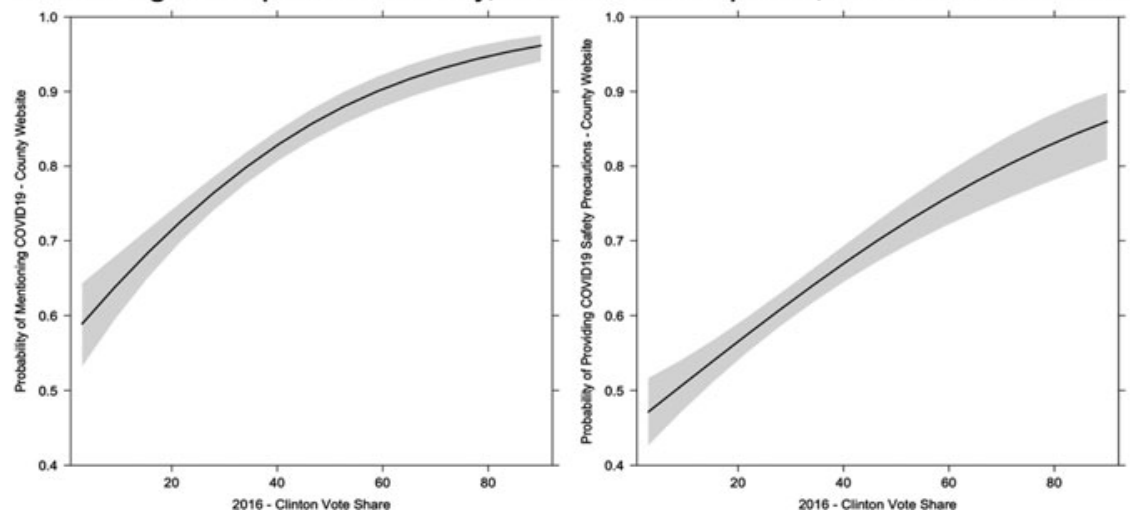

Figure 3 The Effect of Partisanship on County Government Website Information on COVID-19

when comparing a county with the lowest Clinton vote share to the largest Clinton vote share is similar, at around 0.3 . The results indicate that there is a clear statistical relationship between the mass partisanship of a county and the information available to citizens from local governments. In particular, citizens of predominately Democratic counties are more likely to receive information on COVID-19 than are citizens of predominately Republican counties.

\section{Concluding Remarks}

Our analysis builds upon the recent work of scholars who find relationships between partisanship and public policy choices, citizen and elite attitudes and knowledge, and citizen and elite behaviour related to COVID-19 (Armstrong and Lucas, 2020; Gadarian et al., 2020; Merkley et al., 2020; Miller, 2020; Motta et al., 2020; Pickup et al., 2020; van der Linden and Savoie, 2020). In addition, we contribute to the broader research on the relationship between a population's partisanship and local government behaviour (Percival et al., 2009; Choi et al., 2010; Ybarra and Krebs, 2010; Tausanovitch 
and Warshaw, 2014; Einstein and Kogan, 2016). Here, we investigate county websites throughout the United States to understand variance in local government dissemination of information relating to the current pandemic. We find a positive relationship between Democratic vote share in the 2016 election and a county government's dissemination of COVID-19 information on its website. On average, the results indicate that citizens in predominately Republican counties have less opportunity to acquire information and knowledge about the virus on official local government websites. The results demonstrate that even at the local level, partisanship plays a substantive role in the United States' current handling of the pandemic.

Acknowledgments. Hansen acknowledges research funding from a 2019-2020 Menard CSII faculty research stipend from the Menard Center for the Study of Institutions and Innovation and from the Tommy G. Thompson Center on Public Leadership. Hansen and Sadowski acknowledge funding and support from the University of Wisconsin-Parkside's Undergraduate Research Apprenticeship Program (URAP). Sadowski, Blaszcynski and Meyer are undergraduate participants in the Politics, Philosophy, and Law Department's 2020 Undergraduate Research Lab.

\section{Notes}

1 In the state of Alaska, county governments are referred to as boroughs and census areas, and in Louisiana they are referred to as parishes.

2 Fixed effects models accounting for variance by state were estimated as a robustness check. The results confirmed the findings that we present here.

3 As it was relatively early in the pandemic, the mean number of cases was 265.4 and the median number was 12. For deaths, the mean number of deaths was 13.38 and the median was 0.

4 Since there are zero values in the dataset for the COVID-19 cases and deaths variables, we take the log (cases/deaths - MinimumValue(cases/deaths) - 1).

5 We also explored the impact of demographic data at the county level on a subset of counties from the dataset, including median age, education and income level. However, we did not find any meaningful, consistent results worth including in the research note. Population was also included as an independent variable, but the results were substantively the same as population density.

6 Since only two-thirds of states have partisan elections and some of those states have a mix of partisan and nonpartisan elections, we decided to use the traditional presidential vote share measure as a measure of partisanship rather than removing over one-third of the overall sample. As the correlation tests demonstrate, this measure is highly predictive of the county's overall partisanship as well as the partisanship of county governments.

7 We include large single-tier municipalities, such as Houston, in our analysis. Further, when there was debate about including a single-tier municipality due to an issue with a Federal Information Processing Standards (FIPS) code, we double-checked that there was no difference between the municipality and the corresponding county in disseminating information.

8 Additionally, we estimated models where we coded counties that did not have a website as not mentioning COVID-19 or providing safety precautions. The results are substantively similar to the results presented here where the counties without websites are not included in the analysis.

9 Predicted probabilities were calculated holding the independent variables at their median.

\section{References}

Armstrong, David A. II and Jack Lucas. 2020. "Measuring and Comparing Municipal Policy Responses to COVID-19." Canadian Journal of Political Science 53 (2): 227-38.

Baker, David and Roger Chin. 2016. "E-Availability and E-Accessibility of Financial Documents: A State Examination of U.S. County Websites." Electronic Journal of e-Government 14 (1): 73-86.

Bearfield, Domonic A. and Ann O'M. Bowman. 2017. "Can You Find It on the Web? An Assessment of Municipal E-Government Transparency." American Review of Public Administration 47 (2): 172-88. 
Berinsky, Adam J. 2009. In Time of War: Understanding American Public Opinion from World War II to Iraq. Chicago: University of Chicago Press.

Bernick, E. Lee, Jonathan M. Birds, Katheryn Brekken, Al G. Gourrier and Leander D. Kellogg. 2014. "Explaining County Government Fiscal Transparency in an Age of e-Government." State and Local Government Review 46 (3): 173-83.

Choi, Sang Ok, Sang-Seok Bae, Sung-Wook Kwon and Richard Feiock. 2010. "County Limits: Policy Types and Expenditure Priorities." American Review of Public Administration 40 (1): 29-45.

de Benedictis-Kessner, Justin and Christopher Warshaw. 2016. "Mayoral Partisanship and Municipal Fiscal Policy." Journal of Politics 78 (4): 1124-38.

de Benedictis-Kessner, Justin and Christopher Warshaw. 2020. "Politics in Forgotten Governments: The Partisan Composition of County Legislatures and County Fiscal Policies." Journal of Politics 82 (2): 460-75.

Einstein, Katherine Levine and David M. Glick. 2018. "Mayors, Partisanship, and Redistribution: Evidence Directly from U.S. Mayors." Urban Affairs Review 51 (1): 74-106.

Einstein, Katherine Levine and Vladimir Kogan. 2016. "Pushing the City Limits: Policy Responsiveness in Municipal Government.” Urban Affairs Review 52 (1): 3-32.

Gadarian, Shana Kushner, Sara Wallace Goodman and Thomas B. Pepinsky. 2020. "Partisanship, Health Behavior, and Policy Attitudes in the Early Stages of the COVID-19 Pandemic." Preprint, posted March 30. Available at SSRN: https://ssrn.com/abstract=3562796.

Green, Jon, Jared Edgerton, Daniel Naftel, Kelsey Shoub and Skyler J. Cranmer. 2020. "Elusive Consensus: Polarization in Elite Communication on the COVID-19 Pandemic." Science Advances 6 (28): eabc2717. DOI: $10.1126 /$ sciadv.abc2717.

Hansen, Michael A. and Kathleen Dolan. 2020. "Voter Sex, Party, and Gender-Salient Issues: Attitudes about Sexual Harassment and Brett Kavanaugh in the 2018 Elections." American Politics Research 48 (5): 532-42.

Harder, Carolyn T. and Meagan M. Jordan. 2013. "The Transparency of County Websites: A Content Analysis." Public Administration Quarterly 37 (1): 103-28.

Johns Hopkins University. 2020. "COVID-19 United States Cases by County." Coronavirus Resource Center. https://coronavirus.jhu.edu/us-map (April 17, 2020-April 24, 2020).

Lowatcharin, Grichawat and Charles E. Menifield. 2015. "Determinants of Internet-Enabled Transparency at the Local Level: A Study of Midwestern County Web Sites." State and Local Government Review 47 (2): 102-15.

Merkley, Eric, Aengus Bridgman, Peter John Loewen, Taylor Owens, Derek Ruths and Oleg Zhilin. 2020. "A Rare Moment of Cross-Partisan Consensus: Elite and Public Response to the COVID-19 Pandemic in Canada." Canadian Journal of Political Science 53 (2): 311-18.

Miller, Joanne M. 2020. "Psychological, Political, and Situational Factors Combine to Boost COVID-19 Conspiracy Theory Beliefs." Canadian Journal of Political Science 53 (2): 327-34.

Mitchell, Amy, Mark Jurkowitz, J. Baxter Oliphant and Elisa Shearer. 2020. "Three Months In, Many Americans See Exaggeration, Conspiracy Theories and Partisanship in COVID-19 News." Pew Research Center. https://www.journalism.org/2020/06/29/three-months-in-many-americans-see-exaggerationconspiracy-theories-and-partisanship-in-covid-19-news/ (June 29, 2020).

Mondak, Jeffrey J. 1993. "Public Opinion and Heuristic Processing of Source Cues." Political Behavior 15 (2): 167-92.

Motta, Matt, Dominik Stecula and Christina Farhart. 2020. "How Right-Leaning Media Coverage of COVID-19 Facilitated the Spread of Misinformation in the Early States of the Pandemic in the U.S." Canadian Journal of Political Science 53 (2): 335-42.

Percival, Garrick L., Martin Johnson and Max Neiman. 2009. "Representation and Local Policy: Relating County-Level Public Opinion to Policy Outputs.” Political Research Quarterly 62 (1): 164-77.

Pickup, Mark, Dominik Stecula and Clifton van der Linden. 2020. "Novel Coronavirus, Old Partisanship: COVID-19 Attitudes and Behaviors in the United States and Canada." Canadian Journal of Political Science 53 (2): 357-64.

Tausanovitch, Chris and Christopher Warshaw. 2014. "Representation in Municipal Government." American Political Science Review 108 (3): 605-41.

Trump, Donald J. 2020. "Remarks by President Trump, Vice President Pence, and Members of the Coronavirus Task Force in Press Conference." Press Briefings, February 26. https://www.whitehouse. gov/briefings-statements/remarks-president-trump-vice-president-pence-members-coronavirus-task-forcepress-conference/ (June 30, 2020). 
US Census Bureau. 2018. 2014-2018 Five-Year American Community Survey Estimates Public Use Microdata Samples. https://data.census.gov/mdat/\#/search?ds=ACSPUMS5Y2018 (October 24, 2020).

van der Linden, Clifton and Justin Savoie. 2020. "Does Collective Interest or Self-Interest Motivate Mask Usage as a Preventive Measure Against COVID-19?” Canadian Journal of Political Science 53 (2): 391-97.

Wisconsin Supreme Court. Wisconsin Legislature v. Andrea Palm, Julie Willems Van Dijk, and Nicole Safar in Their Official Capacities as Executives of Wisconsin Department of Health Services, [2020] 2020AP765-OA.

Zaller, John. 1992. The Nature and Origins of Mass Opinion. New York: Cambridge University Press.

Cite this article: Hansen MA, Johansson I, Sadowski K, Blaszcynski J, Meyer S (2021). The Partisan Impact on Local Government Dissemination of COVID-19 Information: Assessing US County Government Websites. Canadian Journal of Political Science 54, 150-162. https://doi.org/10.1017/S0008423920000918 